Tomasz Mioduszewski SAC

Warszawa

\title{
Po CO PEDAGOGOM METAFIZYKA REALISTYCZNA?
}

\author{
Do pedagogues need realistic metaphysics?
}

\begin{abstract}
Su m mary: The article attempts to answer the question contained in the title: "Do pedagogues need realistic metaphysics?". In the first part of the text the author explains the difference between the colloquial and philosophical meanings of the term "metaphysics". The author describes realistic metaphysics in accordance with how it is understood by the philosophical school of Lublin. The metaphysical understanding of reality that is described by this school is based on the theory of the analogy of being. The main part of the article is dedicated to this theory. The transcendental features of the intelligibility and desirability of being are discovered, thanks to the existence of the analogy in every being, including human beings. These features are the deepest foundation of the intelligibility and acceptance of the human being, on which pedagogy is based.
\end{abstract}

Keyw ord s: metaphysics, analogy, pedagogy, philosophical school of Lublin.

Co ma na myśli człowiek niezajmujący się na co dzień filozofią, gdy słyszy słowo „metafizyka”? Z czym mu się ono kojarzy? Dla większości osób „metafizyka” czy „metafizyczny” to niedostępny dla zmysłów, ukryty pod powierzchnią tego, co bezpośrednio dane, duchowy, niewyrażalny, nieuchwytny. Stownikjęzyka polskiego, definiując przymiotnik „metafizyczny”, podaje dwa znaczenia. Pierwsze: „odnoszący się do metafizyki”, a drugie znaczenie, potoczne, brzmi: „trudny do zrozumienia; pozazmysłowy, zawiły”. I podaje przykład użycia tego przymiotnika: „Metafizyczny klimat, nastrój jakiegoś utworu"'.

Przypominają mi się rozmowy ze znajomymi krytykami sztuki: z nieżyjącym już Bohdanem Pociejem, krytykiem muzycznym, który w wielu tekstach starał się swoiście filozofować i Bożeną Kowalską, krytykiem sztuk plastycznych, specjalizującą się w polskiej sztuce nowoczesnej. Oni często używali przymiotnika „metafizyczny” do opisu dzieł sztuki niefiguratywnej, abstrakcyjnej w obrazach i muzyki nieprogramowej,

\footnotetext{
${ }^{1}$ Stownik języka polskiego, t. II, red. nauk. Mieczysław Szymczak (Warszawa: PWN 1979), 141. Nowsze wydania niewiele zmieniły w treści tego hasła.
} 
absolutnej. Starałem się w tych rozmowach wskazywać, że takie rozumienie metafizyki dalekie jest od znaczenia filozoficznego. Jeśli nawet cenieni znawcy kultury o znacznym dorobku intelektualnym nie biorą pod uwage podstawowego, ścisłego rozumienia tego terminu, to co mówić oludziach niezwiązanych z humanistyką? Dla wielu jest to obszar raczej przeczucia niż poznania intelektualnego, raczej czegoś idealnego niż realnego, czegoś niematerialnego niż danego w doświadczeniu empirycznym.

Przywołajmy definicję używaną w Filozoficznej Szkole Lubelskiej: metafizyka to „sposób poznawania, w którym rozum posługujący się powszechnymi prawami bytu i myślenia dąży do odkrycia pierwszych i jedynych czynników-przyczyn uniesprzeczniających to, co istnieje, a które zaczątkowo są nam dane w empirycznej intuicji świata materialnego"2.

Metafizyka w sensie ścisłym w filozofii klasycznej jest sposobem poznania, którego przedmiot stanowi to, co istnieje realnie. Odbywa się to w procesie redukcji metafizycznej. Choć podręczniki metodologii nauk określają redukcję jako wnioskowanie nie niezawodne ${ }^{3}$, to redukcja metafizyczna stosowana w Szkole Lubelskiej jest specyficzna. Polega ona na „wskazaniu w samym bycie takiego elementu, którego negacja byłaby negacją samego faktu danego do wyjaśnienia”" ${ }^{\text {. Tak }}$ rozumiana redukcja pozwala na odkrycie w samym bycie czynników, których odrzucenie wikłałoby poznającego w sprzeczność.

Gdy proponujemy pedagogom oparcie swoich poszukiwań naukowych na metafizyce, to propozycja Lubelskiej Szkoły Filozoficznej wydaje się gwarantować realistyczną, wolną od ideologicznych a priori wizję bytu oraz człowieka, który jest przedmiotem zainteresowania pedagogiki. Jednym z najdonioślejszych odkryć szkoły lubelskiej dla metafizyki klasycznej jest teoria analogii. I właśnie analogiczna analiza rzeczywistości pomoże nam wskazać na te czynniki, które pedagogowi będą gwarantowały realistyczny fundament jego naukowych poszukiwań.

Już w pierwszym wydaniu Bytu w 1948 roku Stefan Swieżawski pisał: „[...] bez stosowania analogii w naszym poznaniu i w przeprowadzaniu konstrukcji intelektualnych, mających oddać rzeczywistość, mowy być nie może o metafizyce i teologii. Co więcej, cała rzeczywistość otaczającego nas świata jest z istoty swej analogiczna, analogia przenika niejako sam rdzeń bytu”s.

\footnotetext{
${ }^{2}$ Mieczysław A. Krąpiec, Andrzej Maryniarczyk. „Metafizyka”, W: Powszechna encyklopedia filozofii, red. nacz. Andrzej Maryniarczyk, t. VII (Lublin: Polskie Towarzystwo św. Tomasza z Akwinu 2006), 105.

${ }^{3}$ Por. Zygmunt Hajduk, Ogólna metodologia nauk (Lublin: Wydawnictwo KUL 2011), 55, 60.

4 Tomasz Mioduszewski, Spór o realizm w lubelskiej szkole filozoficznej (Ząbki: Wydawnictwo APOSTOLICUM 2013), 31.

${ }^{5}$ Stefan Swieżawski, Byt. Zagadnienia metafizyki tomistycznej (Lublin: Wydawnictwa TN KUL 1948), 52. To dzieło było jednym z pierwszych i fundamentalnych w początkach filozoficznej szkoły lubelskiej. Wielu myślicieli odnosi się częściej do jego drugiego wydania z 1961 roku, gdzie obok Swieżawskiego jako współautor pojawia się Jaworski. Należy zaznaczyć, że Swieżawski, wspominając o analogii bytu, swoje rozważania rozpoczyna, za Kajetanem, od analogii orzekania. Inną propozycję poda później Krąpiec. Zob. tamże, 53.
} 
Omawiając etymologię słowa „analogia”, Mieczysław Albert Krąpiec podkreśla podwójne znaczenie tego terminu, który oznacza jakiś stan złożonego bytowania rzeczy oraz orzekanie o wielu rzeczach. Lubelski filozof odróżnia na terenie filozofii następujące rodzaje analogii: bytu, poznania, orzekania i wnioskowania. O ile analogie jezzyka i heurezy, a nawet poznania były obecne w filozofii, to opisanie teorii analogii bytu jest oryginalnym wkładem szkoły. Dla uzasadnienia realizmu bytowego i poznawczego należy omówić analogię bytu i poznania. To właśnie analogia, według Andrzeja Maryniarczyka, ma być „bramą” do realizmu poznawczego ${ }^{6}$.

Zdaniem M.A. Krąpca zrozumienie analogii jest kluczem do filozoficznego poznania rzeczywistości ${ }^{7}$. W podstawowym dla tych rozważań tekście Teoria analogii bytu, który kształtował się w latach pięćdziesiątych XX wieku, jego autor zauważa, że nazwa „analogia” „występuje w dziedzinie związanej ze sposobem poznania jakiejś rzeczywistości, i chociaż nie zwykło się jej używać na oznaczenie samej rzeczywistości, to jednak nasze poznanie jest powiązane z realnym przedmiotem, od którego otrzymuje swe pełne zrozumienie. Wobec tego nazwę analogii wolno przenieść na oddanie relatywnych powiązań, jakie tam mają miejsce" . Choć nazwa „analogia” funkcjonowała pierwotnie na terenie filozofii poznania i logiki, to omawiany autor podkreśla, że poznanie analogiczne jest wynikiem analogiczności samej rzeczywistości. Analogia staje się dla Krąpca odpowiedzią na pytanie o połączenie w jednym opisie rzeczywistości pluralizmu bytowego, relatywizmu złożenia bytu oraz determinacji i jedności ontycznej ${ }^{9}$.

W latach pięćdziesiątych XX wieku Krąpiec czuł się jeszcze w obowiązku uzasadnić zapożyczenie terminu ,analogia” z dziedziny rozważań teoriopoznawczych i logicznych do metafizyki. Potem on sam i jego uczniowie posługują się nazwami „analogia metafizyczna” i „analogia bytowa” jako terminami kluczowymi do uzasadnienia realizmu tak ontycznego, jak i poznawczego. Teoria analogii bytu to dzieło, które zdaniem jego autora ma być próbą „rozwiązania kilkusetletniego sporu na temat analogii bytu ujętego metafizycznie"10.

\footnotetext{
${ }^{6}$ Zob. Andrzej Maryniarczyk, „Odkrycie analogicznego sposobu bytowania rzeczy. Sformułowanie teorii poznania analogicznego", w: tegoż, O przyczynach, partycypacji i analogï. Zeszyty z metafizyki $\mathrm{nr} 6$ (Lublin: Polskie Towarzystwo św. Tomasza z Akwinu 2005), 72.

7 Zob. Mieczysław A. Krąpiec, „Analogia”, w: Powszechna encyklopedia filozofii, dz. cyt., 210. Przeciwieństwem analogii bytu są: monizm, wariabilizm oraz izolacjonizm. Ten artykuł został powtórzony z niewielkimi zmianami, zob. Mieczysław A. Krąpiec, „Analogia w filozofii”, W: Analogia $w$ filozofii, red. Andrzej Maryniarczyk, Katarzyna Stępień, Paweł Skrzydlewski (Lublin: Polskie Towarzystwo św. Tomasza z Akwinu 2005), 447-471. Przedstawiony podział rodzajów analogii ma charakter raczej funkcjonalny, to znaczy pokazuje, gdzie stosowana jest analogia. Podział strukturalny wyróżnia analogię proporcjonalności, atrybucji i metafory.

${ }^{8}$ Mieczysław A. Krąpiec, Teoria analogii bytu, Dzieła t. I (Lublin: Wydawnictwo KUL 1993), 184. W Stowie wstepnym, s. 9-11, Krąpiec opisuje dzieje powstania tej fundamentalnej pracy wlatach pięćdziesiątych. W niniejszej pracy wykorzystywane jest wydanie drugie poprawione.

${ }^{9}$ Zob. tamże, 183-184.

${ }^{10}$ Tamże, 9.
} 
Trudno znaleźć w pismach myślicieli z Lubelskiej Szkoły Filozoficznej definicję analogii obejmującą wszystkie jej typy. Najczęściej próbuje się określić jeden z rodzajów analogii: poznania, orzekania lub wynikania. Encyklopedyczne ujęcie bardzo ogólnie mówi o tym, że analogia to: „relacyjna jedność tego, co złożone, odpowiedni stosunek, proporcja, podobieństwo między tym, co zasadniczo różne"11. W innym opracowaniu można przeczytać: „Analogia (gr. analogia - odpowiedni stosunek) - złożone podobieństwo, zwł. oparte na odpowiedniości relacji; upodobnienie przez proporcję"12. Przytaczając jeszcze ogólne, definicyjne określenie: „Analogia w tradycyjnej filozofii jest określana ogólnie jako proporcja ujęta transcendentalnie" ${ }^{13}$.

Etymologia wskazuje na złożoność tego terminu (ana-logein) z przedrostka an-, ana- (podwójny, zwielokrotniony) i logein (składać, mówić, orzekać). A więc analogia oznacza i złożenie rzeczywistości, i orzekanie o tej złożonościit. Sama analogia jest analogiczna, potocznie pojmowana jako „niepodobne podobieństwo”: pomaga określić rzeczy w pewnych aspektach różne, aw innych - podobne. $\mathrm{W}$ orzekaniu, a także $\mathrm{w}$ analizie metafizycznej, sytuuje się między jednoznacznością i wieloznacznością ${ }^{15}$. W podstawowej dla tych rozważań pracy Krąpiec za św. Tomaszem pisze: „Na tle orzekania różnoznacznego i jednoznacznego można by określić analogię jako pewną formę orzekania, oznaczoną wspólną nazwą, której treść realizuje się w podrzędnikach po części tak samo, a po części różnie”16.

W analogii wyróżnia się trzy czynniki: analogat, analogon i relację analogatu do analogonu. Analogon to doskonałość analogiczna, która realizuje się $\mathrm{w}$ analogatach, podmiotach realizacji tej doskonałości. Relacja analogatu do analogonu, trzeci element struktury analogii, wskazuje, że mimo jedności bytu (w wypadku analogii wewnątrzbytowej) analogat nie utożsamia się z analogonem ${ }^{17}$.

${ }^{11}$ Krąpiec, „Analogia”, 210. Zob. Mieczysław A. Krąpiec, Metafizyka. Zarys teorï bytu, Dzieła, t. VII (Lublin: RW KUL 1995), 403-404.

${ }^{12}$ Leksykon filozofii klasycznej, red. nauk. Józef Herbut (Lublin: TN KUL 1997), 40. Hasło „Analogia” w Leksykonie jest w głównej części powtórzeniem z niewielkimi zmianami i skrótami hasła „Analogia” z Encyklopedii katolickiej; Mieczysław A. Krąpiec, „Analogia. W filozofii klasycznej”, W: Encyklopedia katolicka, t. I, (Lublin: TN KUL 1973), 491-498.

${ }^{13}$ Andrzej Maryniarczyk, Metoda separacji a metafizyka (Lublin: Redakcja Wydawnicza KUL 1985), 106. Sam autor twierdzi, że to określenie jest wynikiem lektury rozważań Krąpca na temat analogii.

14 Zob. Krąpiec, „Analogia”, 210; Andrzej Maryniarczyk, Metafizyka w ekologii (Lublin: Wydawnictwo KUL 1999), 168.

15 Zob. Krąpiec, „Analogia”, 210; Andrzej Maryniarczyk, System metafizyki. Analiza „przedmiotowozbornego” poznania (Lublin: RW KUL 1991), 254-255; Maryniarczyk, „Odkrycie”, 78.

${ }^{16}$ Krąpiec, Teoria, 19. Krąpiec często przestrzega przed mieszaniem analogii z izomorfią lub homomorfią. O nietożsamości analogii metafizycznej i izomorfii pisał Józef Herbut, „O formalnym ujęciu analogii transcendentalnej”. Roczniki Filozoficzne 11 z. 1 (1963): 25-40. Autor analizuje właściwości relacji transcendentalnych, które składają się na stosunek analogicznego podobieństwa i znajduje trzy właściwości formalne tego stosunku: symetryczność, przechodniość i przeciwzwrotność („żaden przedmiot nie może być analogiczny do samego siebie"). Natomiast izomorfia jest zawsze stosunkiem symetrycznym, przechodnim i zwrotnym. Zob. tamże, 34-35.

${ }^{17}$ Zob. Krąpiec, „Analogia. W filozofii”, 494; Maryniarczyk, Metoda, 109-110. 
Z analogią mamy do czynienia tam, gdzie występuje mnogość, złożenie, czy to z bytów, czy też samego bytu z jego części składowych. Pluralizm bytowy jest racją analogii międzybytowej ${ }^{18}$. Wewnętrzne złożenie bytu z elementów połączonych ze sobą relacjami dającymi się opisać w kategoriach aktu i możności stanowi wewnątrzbytową analogię. Analogia międzybytowa opiera się na relacjach zachodzących między bytami, ujmowanych wkategoriach przyczyny i skutku: „Struktura analogiczna bytu, związana różnorodnymi relacjami, jest podstawą dla analogii międzybytowej"19. Widać, że Krąpiec wyjaśnia analogię wewnątrzbytową za pomocą teorii aktu i możności ${ }^{20}$, a analogię międzybytową, posługując się relacjami skutku i przyczyny. Oba te elementy, zarówno arystotelesowska teoria aktu i możności, jak też istnienie relacji przyczynowo-skutkowych w rzeczywistości, wchodzą w skład filozofii klasycznej, w ramach której prowadzą swe rozważania omawiani przedstawiciele Filozoficznej Szkoły Lubelskiej. Przy omawianiu analogii Krąpiec nie uzasadnia wymienionych wyżej elementów, są one wyprowadzane winnych miejscach refleksji metafizycznej nad zastaną rzeczywistością daną w poznaniu.

Analogia wewnątrzbytowa wyjaśnia relacyjną tożsamość bytu i jego relacyjną zmienność. Każdy byt przygodny jest analogiczny jako złożony z części powiązanych wieloma relacjami, które przy zmienności nie naruszają tożsamości bytu ${ }^{21}$. Podobnie ma się rzecz z analogią międzybytową, która wyjaśnia wielość różnorodnych bytów w jakimś jednym uniwersum. Ta jedność jest uniesprzeczniona jedną racją istnienia różnorodnych bytów.

Rodzaje relacji, czy to między składnikami bytu, czy między bytami, wyznaczają charakter analogii bytowej. Krąpiec twierdzi, że filozofię interesują przede wszystkim relacje konieczne itranscendentalne, bo one są podstawą metafizyki. Wyróżnia trzy rodzaje takich relacji. Pierwsze są związane z faktycznością bytu, czyli z jego istnieniem, drugie odnoszą się do inteligibilności bytu, a trzecie wynikają z powiązania działania bytu z celem-dobrem: „W przypadku pierwszym mamy do czynienia z konieczną i transcendentalną relacją istoty do istnienia, konstytuującą samą bytowość bytu, która wskazuje na pierwszą sprawczą przyczynę i przyczynowość jako taką. Bytem bowiem jest to, co posiada istnienie, gdyż byt jest ukonstytuowany przez istotę i istnienie, sprzężone jak akt i możność. [...] Istota

18 Według Krąpca pluralizm bytowy jest przyjmowany spontanicznie, podobnie jak pierwotnym, spontanicznym jest fakt stwierdzający istnienie świata. Zob. Krąpiec, Metafizyka, 404.

${ }^{19}$ Krąpiec, „Analogia”, 211. Zob. także Krąpiec, „Analogia. W filozofii”, 493-494; tegoż, Metafizyka, 407408; tegoż, Teoria, 189-190.

20 „Rozumienie teorii aktu i możności wiąże się z rozumieniem samej teorii analogii metafizycznej”, Krąpiec, Teoria, 205.

21 „Fakty zróżnicowania i zmian rzeczy wskazują na ich wewnętrzne złożenie z odmiennych czynników. Podstawowym jest złożenie z zespołu jakichś cech (w języku metafizyki: bytowej treści) oraz aktu istnienia. Takie wewnętrzne złożenie z czynników różnych, lecz koniecznościowo sobie przyporządkowanych i konstytuujących ontyczną jedność rzeczy, nazywa się właśnie analogią wewnątrzbytową", Józef Herbut, Metoda transcendentalna w metafizyce (Opole: Wydawnictwo Św. Krzyża 1987), 10. 
w bycie jest analogatem, tj. nośnikiem odpowiedniej doskonałości analogicznej. Istnienie jest analogonem, a więc tą doskonałością, która «aktualizuje» podmiot-analogat. Nie jest tym samym być analogatem (konkretną treścią) i analogonem jako doskonałością analogiczną, o której się twierdzi, że jest analogicznie jedna. W bycie tą właśnie wspólną doskonałością jest istnienie”22. Dalej Krąpiec wyjaśnia, że tą wspólną doskonałością jest funkcja aktualizowania się istoty przez istnienie. Ale w każdym bycie przygodnym jest to odrębne, niepowtarzalne, własne istnienie, proporcjonalne do danej istoty; ta proporcjonalność jest relacją transcendentalną danego istnienia do aktualizowanej przez nie istoty bytu. Drugim typem relacji transcendentalnej jest relacja bytu do intelektu Absolutu-Stwórcy (czy twórcy w wypadku wytworów). Ta relacja nadaje bytowi cechę inteligibilności. Trzecim typem relacji transcendentalnej, zawartej w bycie, jest relacja do woli-miłości. Jej konsekwencją jest celowość bytu, jego dążenie w działaniu do celu-dobra. Dlatego byt jest amabilny, jest pożądany. Podobnie jak inteligibilność bytu przygodnego, tak i jego amabilność wskazuje na pochodzenie od Absolutu, który chce, by taki byt istniał.

Wymienione relacje transcendentalne zapewniają bytowi jedność i wykluczają prawdziwość metafizycznych systemów monistycznych czy izolacjonistycznych. Analogia bytowa, ukazująca różnorodność relacji koniecznych i transcendentalnych wbycie, pozwala zachować jedność bytu oraz wskazuje na związek bytów przygodnych z Absolutem przez przyczynowanie sprawcze, wzorcze i celowe ${ }^{23}$, co jest podstawą teorii partycypacji, o czym nie będziemy tu mówić, choć jest to bardzo interesujące zagadnienie.

Otóż w tym momencie rozważań można dać odpowiedź na tytułowe pytanie: Po co pedagogom metafizyka realistyczna? Bo taka metafizyka daje najgłębsze uzasadnienie inteligibilności i amabilności każdego bytu, zwłaszcza bytu ludzkiego. Wszystkie nauki poza filozofią zakładają istnienie swego przedmiotu zainteresowań. Tylko filozofia, a ściślej metafizyka, zajmuje się tym, że byt jest, istnieniem, na którym opiera się jego istota, to, czym byt jest. Przedmiotem materialnym pedagogiki jest człowiek i zajmuje się ona jego stroną istotową, ale ugruntowanie tego, czym jest człowiek, znajduje się w tym, co jego istotę aktualizuje, w akcie istnienia. A więc dzięki metafizyce realistycznej dochodzi się do egzystencjalnych podstaw inteligibilności i amabilności człowieka, a nie tylko esencjalnych właściwości bytu ludzkiego.

Inteligibilność bytu realnego, a więc i bytu ludzkiego, wyraża transcendentalną relację bytu do intelektu. W człowieku można „odczytać” swoistą „obecność” intelektu Stwórcy (całe poznanie i nauka, także pedagogika, jest przyswajaniem sobie inteligibilności bytu fundującego porządek racjonalny), co przy jego przygodności wyklucza tożsamość bytu i intelektu, a zmusza do uznania pochodności bytu od intelektu, ujawniając transcendentalną relację bytu do intelektu Absolutu, od którego inteligibilność pochodzi i w którym - i przez którego - wszystko się stało, co jest

${ }^{22}$ Krąpiec, „Analogia”, 211. Zob. tegoż, Metafizyka, 406; Mieczysław A. Krąpiec, „Klasyczne rozumienie filozofii”, w: Powszechna encyklopedia filozofii, red. nacz. Andrzej Maryniarczyk, t. III (Lublin: Polskie Towarzystwo św. Tomasza z Akwinu 2002), 458.

${ }^{23}$ Zob. Krąpiec, „Analogia”, 212. 
bytem. Pochodność od intelektu oraz porządek inteligibilny jest tą podstawową jakością relacyjną, na której są budowane inne wartości-doskonałości bytu ludzkiego.

Amabilność („kochalność”) jest to relacja do woli-miłości konstytuująca porządek dobra i celowości (dynamiczności bytu). Byt ludzki jest amabilny, związany z wolą, bo jest przedmiotem chcenia-pożądania. To w bycie jest powód pożądalności, a jest nim bytowe bogactwo, ujawnione w inteligibilności bytu. Skoro jednak człowiek jest bytem przygodnym, a przez to pochodnym, to swe istnienie realne zawdzięcza Absolutowi, który chce, by taki byt rzeczywiście istniał. Stąd człowiek, jako dobro i źródło pożądalności, jest koniecznościowo i transcendentalnie związany relacją z wolą Absolutu. Człowiek jest (istnieje) dobry, bo jest „chciany-kochany”, a to jest już powód tego, aby realnie istnial. $\mathrm{W}$ analogicznym sposobie istnienia dobra zawiera się relacja transcendentalna pomiędzy bytem ludzkim i wolą bytu osobowego - wolą Absolutu $^{24}$.

Dziś, gdy widzimy w kulturze skupianie się na dobrach stanowiących wyposażenie człowieka, na tym, jaki człowiek jest i jaki ma być, metafizyka realistyczna ukazuje, że najgłębsze racje poznawalności i umiłowania człowieka są w tym, że on jest, że istnieje.

Streszczenie: Artykuł stara się odpowiedzieć na pytanie zawarte w tytule: po co pedagogom metafizyka realistyczna? W pierwszej części autor wyjaśnia różnicę między potocznym a filozoficznym znaczeniem terminu „metafizyka”. Opisuje rozumienie metafizyki realistycznej według Lubelskiej Szkoły Filozoficznej. Metafizyczne rozumienie rzeczywistości opisywane w tej szkole opiera się na teorii analogii bytowej, której poświęcona jest główna część artykułu. Dzięki analogii w każdym bycie, a więc i w bycie ludzkim, odkrywane są transcendentalne właściwości inteligibilności i amabilności. To one stanowią najgłębszy fundament poznawalności i akceptacji bytu ludzkiego, na którym opiera się pedagogika.

Słowa kluczowe: metafizyka, analogia, pedagogika, Lubelska szkoła filozoficzna

\section{Bibliografia}

Hajduk, Zygmunt. Ogólna metodologia nauk. Lublin: Wydawnictwo KUL, 2011.

Herbut, Józef. Metoda transcendentalna w metafizyce. Opole: Wydawnictwo Św. Krzyża, 1987.

Herbut, Józef. „O formalnym ujęciu analogii transcendentalnej”. Roczniki Filozoficzne 11 z. 1 (1963): 25-40.

Krąpiec, Mieczysław A. „Analogia”. W: Powszechna encyklopedia filozofii, red. nacz. Andrzej Maryniarczyk, t. I, 210-220. Lublin: Polskie Towarzystwo św. Tomasza z Akwinu, 2000.

Krąpiec, Mieczysław A. „Analogia. W filozofii klasycznej”. W: Encyklopedia katolicka, t. I, 493-497. Lublin:

Towarzystwo Naukowe Katolickiego Uniwersytetu Lubelskiego, 1973.

${ }^{24}$ Por. Mieczysław A. Krąpiec, „Metafizyka - ogólna teoria rzeczywistości”, w: Mieczysław A. Krąpiec, Stanisław Kamiński, Zofia Zdybicka, Andrzej Maryniarczyk, Piotr Jaroszyński, Wprowadzenie do filozofii, (Lublin: Wydawnictwo KUL 1996), 207. 
Krąpiec, Mieczysław A. „Analogia w filozofii”. W: Analogia w filozofii, red. Andrzej Maryniarczyk, Katarzyna

Stępień, Paweł Skrzydlewski, 447-471. Lublin: Polskie Towarzystwo św. Tomasza z Akwinu, 2005.

Krąpiec, Mieczysław A. „Klasyczne rozumienie filozofii”. W: Powszechna encyklopedia filozofii, red. nacz.

Andrzej Maryniarczyk, t. III, 455-478. Lublin: Polskie Towarzystwo św. Tomasza z Akwinu, 2002.

Krąpiec, Mieczysław A. Metafizyka. Zarys teorii bytu, Dzieta, t. VII. Lublin: RW KUL, 1995.

Krąpiec, Mieczysław A. „Metafizyka - ogólna teoria rzeczywistości”. W: M. Krąpiec, S. Kamiński, Z. Zdybicka,

A. Maryniarczyk, P. Jaroszyński, Wprowadzenie do filozofii, 89-228. Lublin: Wydawnictwo KUL, 1996.

Krąpiec, Mieczysław A. Teoria analogii bytu, Dzieła t. I. Lublin: Wydawnictwo KUL, 1993.

Krąpiec, Mieczysław A., Maryniarczyk. Andrzej, „Metafizyka”. W: Powszechna encyklopedia filozofii, red. naczelny

Andrzej Maryniarczyk, t. VII, 102-116. Lublin: Polskie Towarzystwo św. Tomasza z Akwinu, 2006.

Leksykon filozofii klasycznej, red. nauk. Józef Herbut. Lublin: Towarzystwo Naukowe KUL, 1997.

Maryniarczyk, Andrzej. Metafizyka w ekologii. Lublin: Wydawnictwo KUL, 1999.

Maryniarczyk, Andrzej. Metoda separacji a metafizyka. Lublin: Redakcja Wydawnicza KUL, 1985.

Maryniarczyk, Andrzej. O przyczynach, partycypacji i analogii. Zeszyty z metafizyki nr 6, 71-86. Lublin:

Polskie Towarzystwo św. Tomasza z Akwinu, 2005.

Maryniarczyk, Andrzej. System metafizyki. Analiza „przedmiotowo-zbornego” poznania. Lublin: RW KUL, 1991.

Mioduszewski, Tomasz. Spór o realizm w lubelskiej szkole filozoficznej. Ząbki: APOSTOLICUM, 2013.

Stownikjęzyka polskiego, t. II, red. nauk. Mieczysław Szymczak. Warszawa: PWN, 1979.

Swieżawski, Stefan. Byt. Zagadnienia metafizyki tomistycznej. Lublin: Wydawnictwa TN KUL, 1948. 